\title{
Cell Ontogeny
}

National Cancer Institute

\section{Source}

National Cancer Institute. Cell Ontogeny. NCI Thesaurus. Code C19560.

Development of the individual cell, as disting uished from phylogeny, which is evolutionary development of the species. 